\title{
Pengujian Monday Effect pada Indeks LQ-45 di Bursa Efek Indonesia pada saat Pandemi
}

\author{
Komang Bagus Surya Kepakisan ${ }^{1}$ \\ Fakultas Ekonomi dan Bisnis \\ Universitas Udayana, Indonesia
}

\author{
I Gst Ayu Eka Damayanthi² \\ Fakultas Ekonomi dan Bisnis \\ Universitas Udayana, Indonesia
}

Surel : suryakepakisan33@gmail.com

\section{ABSTRAK}

Penelitian di Indonesia banyak ditemukan adanya anomali pada pasar modal, salah satunya yaitu fenomena Monday effect. Keberagaman hasil penelitian mendorong untuk melakukan penelitian kembali tentang fenomena Monday effect pada kondisi berbeda yaitu pandemi. Tujuan penelitian ini yaitu untuk mengetahui terjadinya Monday effect pada perusahaan di Bursa Efek Indonesia pada saat pandemi. Penelitian ini dilakukan pada seluruh perusahaan LQ-45 pada bulan Maret sampai Oktober tahun 2020. Pengumpulan data dengan melakukan pengamatan terhadap data sekunder yang telah tersedia. Teknik analisis yang digunakan yaitu uji one sample t-test. Penelitian ini membuktikan bahwa tidak terdapat perbedaan rata-rata return pada hari senin dan fenomena Monday effect tidak terjadi pada saat pandemi.

Kata Kunci: $\quad$ Monday Effect; Indeks LQ-45; Bursa Efek Indonesia.

\section{Testing the Monday Effect on the LQ-45 Index on the Indonesia Stock Exchange during a Pandemic}

\section{ABSTRACT}

Research in Indonesia found many anomalies in the stock market, such as the Phenomenon of Monday effect. The diversity of research results encourages to re-research the Phenomenon of Monday effect on different conditions, namely pandemic. The purpose of this study is to find out the occurrence of Monday effect on the Indonesia Stock Exchange at the time of the pandemic. This research was conducted on all LQ-45 companies in March to October 2020. Data collection by observing the available secondary data. The analysis technique used is one sample t-test. This research proves that there is no difference in average return on Monday which the phenomenon of Monday effect doesn't occur during a pandemic.

Keywords: $\quad$ Monday Effect; LQ-45 Index; Indonesia Stock Exchange.

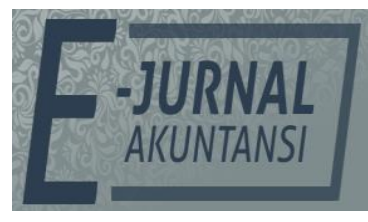

e-ISSN 2302-8556

Vol. 31 No. 9

Denpasar, September 2021 Hal. 2378-2387

DOI:

10.24843/EJA.2021.v31.i09.p18

PENGUTIPAN:

Kepakisan, K.B.S., \& Damayanthi, I.G.A.E. (2021).

Pengujian Monday Effect pada Indeks LQ-45 di Bursa

Efek Indonesia pada saat

Pandemi. E-Jurnal Akuntansi, 31(9), 2378-2387

RIWAYAT ARTIKEL: Artikel Masuk: 15 Juli 2021

Artikel Diterima: 12 September 2021

Artikel dapat diakses : https://ojs.unud.ac.id/index.php/Akuntansi/index 


\section{PENDAHULUAN}

Pasar modal sangat dibutuhkan sebagai alternatif untuk investasi pada finansial aset. Pasar modal juga merupakan fasilitas untuk menjembatani antara pihak yang memiliki kelebihan dana dengan pihak yang membutuhkan dana. Pihak yang memiliki kelebihan dana akan berupaya memperoleh return saham dari aktivitas perdagangan di pasar modal.

Menurut teori pasar efisien, investor hanya mendapatkan return yang normal karena tidak akan pernah ada pola pergerakan harga yang konstan setiap harinya yang dapat di manfaatkan untuk memperoleh abnormal return secara konsisten (Agustina, 2016). Namun, teori pasar efisien tidak selamanya bisa diaplikasikan di dalam pasar modal. Banyak penelitian pada pasar modal menemukan adanya suatu ketidakberaturan yang terdeteksi dan berdampak cukup signifikan yang akhirnya digolongkan sebagai anomali pasar, salah satu dari anomali tersebut adalah day of the week effect. Suatu fenomena yang merupakan bentuk anomali dari teori pasar yang efisien disebut Day of the week effect, dimana rata-rata return harian berbeda untuk setiap harinya dalam satu minggu. Hal ini bertentangan dengan hipotesis pasar efisien yang mengatakan bahwa return saham sama pada setiap hari perdagangan. Beberapa penilitian tentang day of the week effect menunjukkan return pasar negatif terjadi pada hari Senin (Monday effect).

Beberapa penelitian di dalam maupun luar negeri menemukan adanya fenomena day of the week effect, dimana peneliti menunjukkan adanya return negatif pada hari pembukaan perdagangan pada hari Senin (Monday effect). Penelitian yang dilakukan oleh Rahmawati \& Hidayati (2016), berhasil menemukan adanya fenomena day of the week effect pada perdagangan saham di Bursa Efek Indonesia dimana return negatif terjadi pada hari Senin (Monday effect). Salah satu penelitian yang menemukan fenomena anomali pasar di luar negeri adalah penelitian yang dilakukan oleh Muhammad \& Rahman (2010) yang menemukan adanya fenomena day of the week effect pada negara Malaysia. McGowan \& Ibrihim (2009) menemukan adanya fenomena day of the week effect pada Rusia Stock Market. Investor cenderung tidak bersemangat pada hari Senin, karena hari Senin adalah hari pertama bekerja yang panjang dalam seminggu (Rystrom \& Benson, 1989).

Wabah penyakit virus corona terjadi pada awal tahun 2020. Wabah ini menghebohkan Indonesia dan berbagai negara. Wabah ini masuk ke Indonesia tepatnya pada tanggal 2 Maret 2020, berdampak pada perekonomian di berbagai negara dan berimbas pada pasar modal. Bursa Efek Indonesia (BEI) sebagai pasar modal di Indonesia terkena dampak dari wabah virus corona ini.

Pada kondisi pasar yang normal fenomena Monday effect ini sering terjadi, tetapi kondisi pasar yang berbeda saat ini karena adanya pandemi peneliti ingin melakukan pengujian apakah fenomena Monday effect tetap terjadi atau tidak. Penelitian ini menggunakan periode pengamatan pada saat terjadi pandemi bulan Maret 2020 sampai dengan Oktober 2020. Judul yang diambil dalam penelitian ini adalah "Pengujian Monday effect pada Indeks LQ-45 di Bursa Efek Indonesia pada saat Pandemi".

Hipotesis pasar efisien atau efficient market hypothesis (EMH) merupakan topik yang menjadi perhatian luas sejak tahun 1970-an. Fama (1970) menjelaskan 
bahwa pasar dikatakan efisien apabila harga-harga yang terbentuk di pasar mencerminkan secara penuh informasi-informasi yang ada. Pasar dikatakan efisien jika investor individu maupun investor institusi tidak dapat memperoleh abnormal return dalam jangka waktu yang panjang dengan menggunakan strategi perdagangan yang ada. Menurut Perez (2018) pasar modal dikatakan tidak efisien jika perusahaan berada dalam situasi yang mempengaruhi operasi bisnisnya dan informasi yang tersedia untuk umum, tetapi tindakan perusahaan tidak mengubah harga pasarnya. Jika hal ini terjadi, maka para investor dapat memanfaatkan fenomena ini dan menyusun strategi agar mendapatkan abnormal return.

Perubahan harga yang terjadi bersifat independen satu dengan lainnya dan bergerak secara random karena informasi yang memengaruhi harga sekuritas tersebut random. Hal ini berarti bahwa perubahan harga yang terjadi hari ini tidak bergantung pada perubahan harga yang terjadi di masa lalu karena harga baru tersebut berdasarkan reaksi para investor terhadap informasi baru yang terjadi secara random. Dalam hal ini harga pasar merupakan harga saham yang ditentukan dan dibentuk oleh mekanisme pasar modal (Apsari, 2018).

Anomali pasar adalah suatu strategi atau teknik yang berlawanan atau bertentangan dengan konsep pasar modal yang efisien dan penyebab kejadian tersebut tidak dapat dengan mudah menjelaskan penyebab dari peristiwa tersebut. Menurut Jones (1996) dalam (Hartono, 2017:664) mendefinisikan bahwa anomali pasar (market anomaly) sebagai strategi atau tenkik yang bertentangan dengan pasar modal yang efisien. Pola pergerakan return yang konstan ini dapat di prediksi oleh para investor secara anomali, sehingga fenomena anomali ini dapat dimanfaatkan investor untuk mendapat abnormal return yang lebih besar (Koesoemasari et al., 2018). Menurut Roseliani \& Khairunnisa (2015) menyebutkan terdapat 4 jenis anomali pasar yaitu anomali perusahaan (firm anomalies), anomali musiman (seasonal anomalies), anomali peristiwa atau kejadian (event anomalies), dan anomali akuntansi (accounting anomalies).

Konsep dari efisiensi pasar modal akan selalu dikaitkan dengan adanya anomali pasar. Cederburg \& O'Doherty (2015) menyatakan bahwa anomali adalah return saham rata-rata yang tidak konsisten dengan model perilaku harga aset yang berlaku. Menurut Banz (1981) mengatakan anomali juga terjadi pada sekuritas kecil. Sekuritas yang berada di NYSE yang berukuran kecil memberikan return yang besar dibandingkan dengan sekuritas yang berukuran besar. Anomali pasar sangatlah penting untuk diketahui dan dipelajari karena para investor dapat membuat strategi perdagangan untuk mendapatkan abnormal return (Shahid \& Mehmood, 2015).

Pasar akan terjadi anomali jika terdapat suatu perubahan yang terjadi secara berulang atau terus-menerus yang akhirnya dapat di prediksi (Putra \& Ardiana, 2016). Anomali tersebut akan membuat para investor yang sebelumnya tidak mengetahui adanya perubahan yang terjadi secara random menjadi tahu dan dapat membuat prediksi dari satuan waktu sehingga tidak lagi terjadi secara random. Dengan adanya anomali ini, investor dapat mengambil keputusan dalam membeli saham perusahaan dalam waktu tertentu. Adanya anomali ini disebabkan oleh tiga hal (Trisnadi \& Sedana, 2016). Pertama, ketidaksempurnaan sebuah struktur pasar, di mana tidak ada pasar yang bisa kita sebut sempurna 
pada kenyataannya. Kedua, adanya penyimpangan perilaku investor yang memiliki kekuatan cukup besar dalam melakukan perdagangan. Ketiga, terjadi kesalahan dalam penilaian pasar modal karena para investor menggunakan referensi teori pasar modal dalam melakukan strategi investasi kurang tepat.

Monday effect merupakan salah satu bagian dari the day of the week effect yaitu suatu seasonal anomalies (anomali musiman) atau calendar effect (efek kalender) yang terjadi pada pasar financial yaitu ketika harga saham pada hari Senin negatif secara signifikan (Mehdian \& Perry, 2001). Menurut Wulandari \& Diana (2018) Monday effect dapat terjadi akibat dipengaruhi oleh pola perilaku investor yang tidak rasional dalam melakukan perdagangan hari Senin. Monday Effect adalah anomali yang sangat berpengaruh terhadap sebagian harga saham di dunia (Nasir et al., 2017). Aktivitas perdagangan yang tinggi pada hari Senin didorong oleh keinginan investor individu untuk menjual saham lebih tinggi daripada keinginan untuk membeli saham, sehingga menyebabkan harga saham yang lebih rendah untuk perdagangan pada hari Senin dibandingkan dengan hari perdagangan yang lainnya.

Terdapat 4 faktor terjadinya Monday effect dilihat dari sudut institusional investor Sias \& Starks, (1995) salah satunya yaitu institusional investor menghindari perdagangan pada hari Senin dimana institusional investor menggunakan hari Senin sebagai waktu untuk merencanakan strategi. Namun, menurut Jaisinghani, (2016) mengatakan bahwa sejauh ini belum ada kesepakatan bersama tentang pemicu terjadinya fenomena Monday Effect pada hari Senin mengalami harga terendah walaupun sudah banyak penelitian serupa yang telah dilakukan.

Indeks LQ-45 adalah indeks saham dari 45 saham perusahaan publik yang dapat diperjualbelikan di Bursa Efek Indonesia (BEI) (Rahmawati \& Hidayati, 2016). Indeks LQ-45 merupakan gabungan kelompok 45 saham terbaik dengan tingkat kapitalisasi pasar yang besar dan likuiditas tinggi, karena sahamnya aktif diperdagangkan oleh investor sehingga indeks LQ-45 menjadi indeks saham yang peka terhadap adanya perubahan informasi-informasi yang masuk ke dalam pasar. Karena indeks ini peka terhadap informasi yang masuk ke dalam pasar, maka indeks ini tepat digunakan untuk membuktikan teori pasar efisien yang mengatakan bahwa harga-harga yang terbentuk di pasar mencerminkan secara penuh informasi-informasi yang ada. Indeks LQ-45 bertujuan untuk menyediakan sarana yang obyektif dan terpercaya bagi investor, manajer investasi, analisis keuangan, dan pemerhati pasar modal lainnya dalam memonitor pergerakan harga dari saham-saham yang aktif diperdagangkan (Saraswati et al., 2015).

Return saham adalah imbalan yang diterima oleh para investor atas keberaniannya mengambil risiko atas modal yang ditanamkan dengan berinvestasi di pasar modal berupa return realisasian dan return ekspektasian (Indrayani, 2019). Menurut Sulaiman \& Handi (2008) return saham secara umum adalah keuntungan yang diperoleh dari kepemilikan saham investor dalam suatu investasi yang dilakukannya yang terdiri atas deviden dan keuntungan modal atau kerugian modal.

Pada kondisi pasar yang normal banyak dilakukan penelitian terkait anomali di pasar modal untuk menguji teori pasar efisien. Salah satu argumentasi yang menolak teori pasar efisien adalah fenomena anomali yang terjadi baik di 
pasar modal dan di pasar uang. Dengan melihat return setiap harinya pasar modal bisa dikatakan efisien jika return setiap harinya tidak ada perbedaan yang signifikan. Dalam penelitian ini ingin mebuktikan apakah dalam kondisi pasar yang berbeda ini terjadi atau tidak fenomena anomali Monday effect yang mengatakan bahwa return hari Senin berbeda dengan hari selain Senin. Hasil penelitian sebelumnya menunjukkan bahwa adanya return negatif pada penutupan perdagangan hari Senin yang disebut Monday effect. Menurut Agustina (2016), terjadi fenomena Monday effect pada indeks LQ-45 di Bursa Efek Indonesia karena dilihat dari rata-rata return pada hari Senin menunjukkan hasil yang negatif dari pada hari lainnya. Fenomena ini terjadi karena faktor psikologis dari investor yang berperilaku kurang rasional dan bergantung pada mood masingmasing investor.

Hasil penelitian dimana hari Senin menunjukkan return yang negatif atau disebut Monday effect. Penelitian Gibbons \& Hess (1981), menemukan bahwa return pada hari Senin lebih rendah dibandingkan pada hari lainnya di NYSE (New York Stock Exchange). Rossi (2015) meneniliti bahwa return saham secara signifikan negatif pada hari Senin dan secara signifikan lebih rendah daripada return saham untuk hari selain Senin di AS. Penelitian di berbagai Negara lain juga menemukan bahwa terjadi Monday effect di antaranya Negara Amerika Serikat, Inggris, Perancis dan Kanada (Wang, Li, \& John, 1997).

Hasil penelitian lain menyimpulkan bahwa keinginan investor untuk menjual saham pada hari Senin lebih besar dari pada keinginan membeli. Investor menjual saham pada hari Senin karena para investor cenderung menghabiskan uangnya untuk membeli sesuatu atau untuk bersenang-senang pada hari libur. Kejadian itu akan menyebabkan harga saham pada hari Senin akan lebih rendah dari pada harga saham hari selain Senin. Dengan demikian hipotesis yang diajukan yaitu terjadi Monday effect pada indeks LQ-45 di Bursa Efek Indonesia pada saat pandemi.

\section{METODE PENELITIAN}

Penelitian ini menggunakan analisis statistik deskriptif dengan observational. Obyek dalam penelitian ini adalah seluruh perusahaan LQ-45. Penelitian ini menggunakan seluruh perusahaan yang terdaftar LQ-45 pada tahun 2020 yang terdaftar di Bursa Efek Indonesia (BEI). Jenis data yang digunakan pada penelitian ini, yaitu menggunakan data sekunder yang meliputi harga penutupan saham indeks yang tergabung dalam LQ-45 untuk mengetahui return setiap harinya yang diperoleh dari situs internet www.idx.co.id dan id.investing.com. Harga penutupan digunakan untuk mencari return harian sehingga membutuhkan harga akhir di setiap hari perdagangan selesai.

Variabel dalam penelitian ini adalah return saham. Return saham ini digunakan untuk membuktikan apakah pasar modal Indonesia terjadi fenomena Monday effect. Dengan menghitung return saham setiap harinya, selanjutnya diuji dengan membandingkan nila rata-rata return saham hari Senin dengan nol. Jika hari Senin berbeda dengan nol, maka pasar modal Indonesia terjadi fenomena Monday effect. Sebaliknya, jika hari Senin tidak berbeda dengan nol maka pasar modal Indonesia dapat dikatakan efisien. 
Definisi operasional dan pengukuran yang digunakan dalam penelitian ini adalah return saham. Variabel return saham dapat diukur dengan menggunakan rumus berikut.

Rit $=\mathrm{Pt}-\mathrm{Pt}-1 / \mathrm{Pt}-1$

Keterangan:

Rit = Return saham harian pada hari ke-t

$\mathrm{Pt} \quad=$ Harga saham penutupan pada hari ke-t

Pt-1 = Harga saham penutupan pada hari sebelumnya ( $\mathrm{t}-1)$

Populasi dalam penelitian ini adalah saham-saham di Bursa Efek Indonesia (BEI). Pengambilan sampel yang digunakan dalam penelitian ini, yaitu dipilih dengan metode purposive sampling. Kriteria pemilihan sampel pada penelitian ini adalah perusahaan yang terdaftar sebagai indeks LQ-45 di Bursa Efek Indonesia pada bulan Maret - Oktober tahun 2020. Alasan pengambilan sampel bulan Maret - Oktober tahun 2020 ingin mengambil 30 sampel dari awal terjadi pandemi. Teknik analisis data yang digunakan yaitu statistik deskriptif, uji normalitas dan uji one sampel $t$-test. Analisis ini menggunakan bantuan SPSS.

\section{HASIL DAN PEMBAHASAN}

Analisis statistik deskriptif ini akan dijelaskan bagaimana rata-rata return harian selama periode penelitian yaitu bulan Maret 2020 - Oktober 2020 pada sahamsaham perusahaan yang masuk dalam sampel penelitian di indeks LQ-45.

\section{Tabel 1. Hasil Analisis Statistik Deskriptif}

\begin{tabular}{llllll}
\hline Hari & N & Minimin & Maksimum & Rata-rata & $\begin{array}{l}\text { Deviasi } \\
\text { Standar }\end{array}$ \\
\hline Senin & 32 & $-0,083$ & 0,049 & $-0,008$ & 0,028 \\
Selasa & 35 & $-0,066$ & 0,050 & 0,004 & 0,022 \\
Rabu & 32 & $-0,044$ & 0,034 & $-0,002$ & 0,019 \\
Kamis & 31 & $-0,066$ & 0,149 & $-0,001$ & 0,038 \\
Jumat & 29 & $-0,035$ & 0,073 & 0,005 & 0,022 \\
\hline
\end{tabular}

Sumber: Data Penelitian, 2020

Berdasarkan Tabel 1, hari Senin menunjukkan rata-rata return berkisar antara $-0,083$ hingga 0,049 , dengan rata- rata return sebesar $-0,008$. Hal ini menunjukkan bahwa sebagian besar saham turun pada hari Senin. Pada hari Selasa rata-rata return berkisar antara $-0,066$ hingga 0,050 , dengan rata-rata return sebesar 0,004 . Hal ini menunjukkan bahwa sebagian besar saham naik pada hari Selasa. Pada hari Rabu rata-rata return berkisar antara -0,044 hingga 0,034, dengan rata-rata return sebesar $-0,002$. Hal ini menunjukkan bahwa pada hari Rabu sebagian besar saham terjadi penurunan bila dibandingkan dengan rata-rata hari Selasa. Pada hari Kamis rata-rata return berkisar antara -0,066 hingga 0,149, dengan rata-rata return sebesar $-0,001$. Hal ini menunjukkan bahwa pada hari Kamis sebagian besar saham terjadi penurunan. Pada hari Jumat rata-rata return berkisar antara $-0,035$ hingga 0,073, dengan rata-rata return sebesar 0,005. Hal ini menujukkan bahwa pada hari Jumat sebagian besar saham mengalami kenaikan jika dibandingkan dengan rata-rata pada hari Kamis. Hari Kamis memiliki nilai standar deviasi sebesar 0,038, paling besar dibandingkan hari lainnya. Hal ini menunjukkan bahwa hari Kamis memiliki risiko tertinggi dibandingkan dengan hari perdagangan lainnya. Hari Rabu memiliki nilai standar deviasi sebesar 0,019, 
paling kecil dibandingkan hari lainnya. Hal ini dapat menunjukkan bahwa risiko pada hari Rabu paling kecil jika dibandingkan dengan hari perdagangan lainnya.

Penelitian ini diuji terlebih dahulu menggunakan uji normalitas dan selanjutnya diuji dengan metode pengujian one sample t-test. Uji normalitas menunjukan bahwa data pada kelompok hari Senin diperoleh nilai signifikansi sebesar 0,190. Oleh karena nilai signifikansi lebih besar dari 0,05, maka data dinyatakan terdistribusi normal dan dapat dilanjutkan untuk pengujian hipotesis dengan metode uji one sample t-test.

Pengujian hipotesis menggunakan metode uji one sample t-test dilakukan untuk mengetahui terdapat atau tidaknya fenomena Monday effect di Bursa Efek Indonesia selama periode penelitian yang ditentukan dari nilai return saham perusahaan yang terdaftar dalam indeks LQ-45 dan diuji menggunakan alat statistik one sample t-test. Tabel 2, adalah ringkasan hasil uji beda yang telah dilakukan dengan menggunakan SPSS.

Tabel 2. Hasil Uji One Sampel T-Test

Test Value $=0$

Sig. (2-tailed)

Senin $\quad 0,109$

Sumber: Data Penelitian, 2020

Uji one sampel t-test menunjukkan bahwa hasil dari membandingkan nilai rata-rata return saham hari Senin dengan nol menunjukkan hasil uji one sample ttest diperoleh nilai signifikansi sebesar 0,109. Sig. (2-tailed) $>0,05(0,109>0,05)$, maka Ho diterima. Maka, hipotesis yang menyatakan terjadi fenomena Monday effect pada perusahaan LQ 45 di Bursa Efek Indonesia pada saat pandemi, ditolak. Dengan demikian dapat disimpulkan bahwa return saham hari Senin tidak berbeda dari nol dan tidak terjadi fenomena Monday effect pada indeks LQ-45 di Bursa Efek Indonesia pada saat pandemi.

Berdasarkan hasil analisis statistik deskriptif pada Tabel 1, menunjukkan rata-rata return hari Senin menjadi hari dengan rata-rata return saham terendah selama lima hari perdagangan pada periode penelitian. Meskipun demikian pada hasil uji one sample t-test mendapatkan hasil yakni dengan nilai sig. 0,109 yang mana nilai tersebut lebih besar dari nilai signifikansi 0,05. Data tersebut menyatakan bahwa pada Bursa Efek Indonesia tidak terdapat perbedaan return yang signifikan pada hari Senin. Dengan itu kondisi pasar modal Indonesia pada saat pandemi dapat dikatakan efisien karena harga sangat peka terhadap informasi yang ada. Pada kondisi pasar yang berbeda hasil ini sesuai dengan penelitian yang telah dilakukan oleh Ardinan (2014) yang menyatakan bahwa tidak terjadi fenomena Monday effect pada indeks LQ-45 selama periode 2010-2012.

Penyebab tidak terjadinya fenomena Monday effect tersebut disebabkan karena kondisi pasar di Indonesia sedang tidak baik dikarenakan berbagai sentimen negatif yang beredar memukul perekonomian di Indonesia, bahkan ekonomi dunia karena adanya infeksi virus corona. Perubahan perilaku investor juga bisa menjadi penyebab tidak terjadinya fenomena Monday effect. Hal ini mengakibatkan pola return saham harian sulit ditebak pada kondisi pandemi ini. Bisa dilihat dalam Gambar 1 data historis harga saham indeks LQ-45 periode Maret 2020 - Oktober 2020. 
Data Historis Indeks LQ45

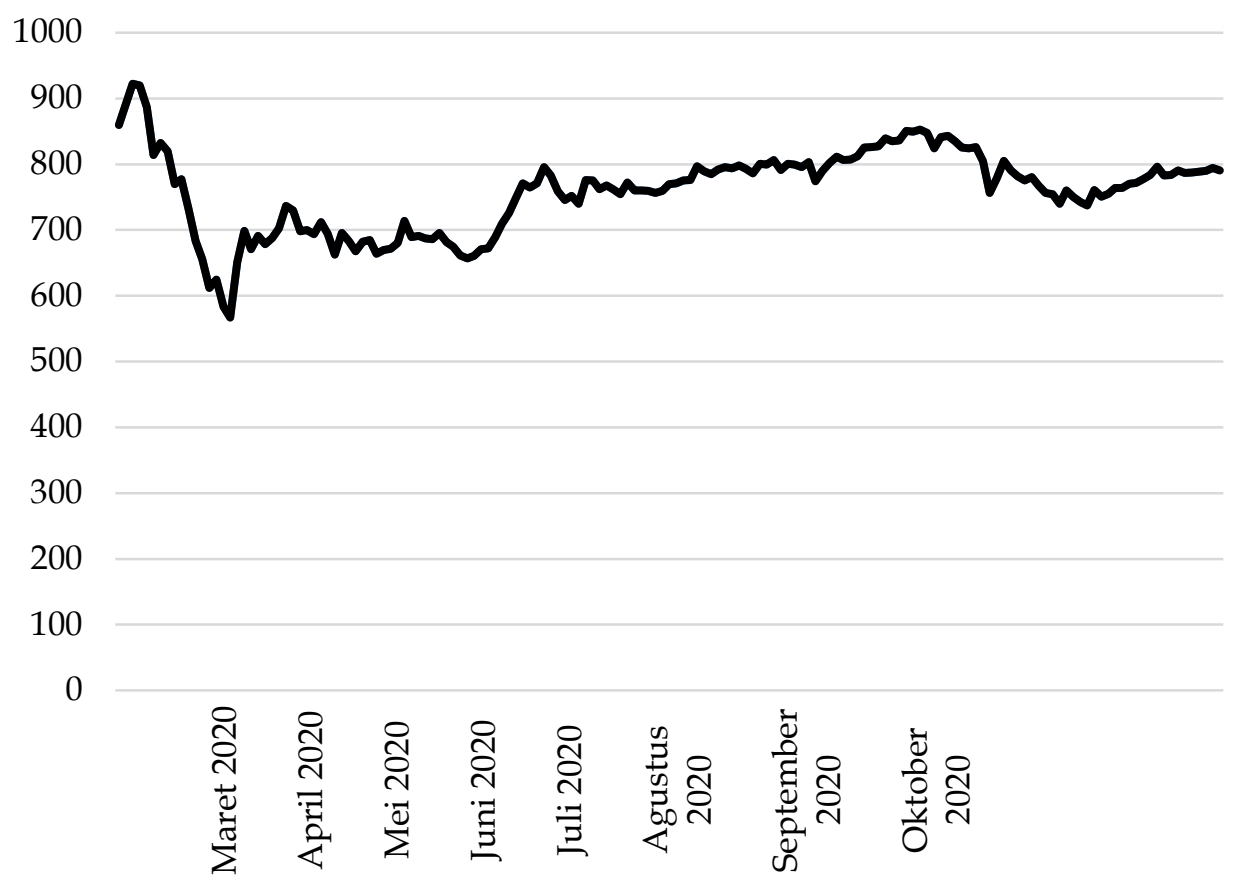

Gambar 1. Data Historis Indeks LQ-45 Bulan Maret 2020 - Oktober2020 Sumber: id.investing.com, 2020

Dilihat pada Gambar 1, awal bulan Maret terjadi penurunan harga yang sangat drastis yang disebabkan oleh sentimen negatif tentang virus corona. Pada perdagangan 9 Maret 2020, indeks LQ-45 ditutup turun hingga 8,26 persen. Kejadian yang sangat langka indeks LQ-45 bisa turun sangat besar. Penurunan harga yang sangat drastis membuat Bursa Efek Indonesia mengambil tindakan dengan mengeluarkan sebuah kebijakan. Pada tanggal 12 Maret 2020, berdasarkan Peraturan No. II-A Tentang Perdagangan Efek Bersifat Ekuitas dengan SK Direksi No: KEP-00025/BEI/03-2020 diambil dari website idx.co.id, batas auto reject apabila terjadi penurunan harga saham sebesar 7 persen untuk semua rentang harga saham. Namun, batas auto reject apabila terjadi kenaikan harga saham tetap tidak berubah pada semua rentang harga saham. Kebijakan ini digunakan untuk menahan kepanikan yang terjadi pada pasar modal Indonesia.

\section{SIMPULAN}

Berdasarkan hasil penelitian ini Bursa Efek Indonesia tidak menunjukan perbedaan return yang signifikan pada hari Senin dan fenomena Monday Effect tidak terjadi. Hal ini disebabkan karena berbagai sentimen negatif yang beredar pada saat pandemi karena adanya virus corona. Sentimen negatif tersebut adalah pertambahan kasus positif Covid-19 di Indonesia. Sentimen ini lebih ditakuti oleh banyak pelaku bisnis karena berpotensi membuat prospek bisnis dan kinerja perusahaan terganggu. Perubahan perilaku investor juga bisa menjadi penyebab tidak terjadinya fenomena Monday effect yang dilihat dari data historis indeks LQ45, investor melakukan panic selling karena takut perusahaan yang dibeli akan 
mengalami kerugian pada saat pandemi dilihat dari penurunan harga saham yang sangat dalam pada awal pandemi. Hal ini mengakibatkan pola return saham harian sulit ditebak pada kondisi pandemi ini. Bagi perusahaan dapat memberikan informasi kepada investor baik dari aspek teknikal maupun fundamental agar para investor ingin berinvestasi di perusahaan tersebut. Analisis laporan keuangan dan analisis rasio adalah bagian penting dalam analisis fundamental, sedangkan analisis teknikal dapat menggunakan data historis. Bagi investor saat ingin berinvestasi dalam kondisi pandemi dapat mempertimbangan agar berhati-hati dalam membeli saham, karena cenderung harga saham mengalami penurunan. Investor dapat menyusun strategi untuk mengambil keputusan pembelian saham yang akan datang apabila terjadi kondisi seperti ini lagi. Bagi peneliti selanjutnya disarankan untuk mengganti objek data penelitian dan menambah sampel serta periode penelitian agar menjadi penelitian tidak hanya dalam jangka pendek saja tetapi dalam jangka panjang dalam kondisi yang berbeda seperti pandemi ini. Sehingga akan diperoleh hasil yang lebih baik dan lebih akurat serta dapat memberikan keuntungan lebih bagi para investor maupun para calon investor.

\section{REFERENSI}

Agustina, Kurnia. (2016). Pengujian Fenomena Monday Effect Di Bursa Efek, Shanghai \& New York. STIE Perbanas Surabaya, 1-12.

Apsari, A. D. (2018). Pengujian Fenomena Monday Effect Di Bursa Eefek Indonesia, Shanghai Dan Thailand. STIE Perbanas Surabaya, 1-10.

Ardinan, H. (2014). Pengujian Monday Effect Pada Bursa Efek Indonesia Dan Bursa Efek Singapura. Journal of Business and Banking, 4(1), 81-90.

Banz, R. W. (1981). The Relationship Between Return and Market Value of Common Stocks. Journal of Financial Economics, 9.

Cederburg, S., \& O’Doherty, M. S. (2015). Asset-pricing anomalies at the firm level. $\begin{array}{llll}\text { Journal of } & \text { Econometrics, } & 186(1),\end{array}$ https://doi.org/10.1016/j.jeconom.2014.06.004

Fama, E. F. (1970). Efficient Capital Markets: A Review of Theory and Empirical Work. American Heart Journal, 25(2), 383-417. https://doi.org/10.1016/00028703(53)90182-3

Gibbons, M. R., \& Hess, P. (1981). Day of the Week Effects and Asset Returns. The Journal of Business, 54(4), 579-596. https:/ / doi.org/10.1086/296147

Hartono, J. (2017). Teori Portofolio dan Analisis Investasi. Edisi 11.

Indrayani. (2019). Analisis Fenomena January Effect Pada Saham Sektor Pertambangan Yang Terdaftar Di Bursa Efek Indonesia (BEI). Jurnal Ekonomi Manajemen E Bisnis, 20(1), 39-50.

Jaisinghani, D. (2016). South Asian Journal of Global Business Research: An Empirical Test of Calendar Anomalies for the Indian Securities Markets. South Asian Journal of Global Business Research, 5(1).

Koesoemasari, Haryono, T., \& Safitri, D. (2018). Monday Effect, Week-Four Effect and January Effect in Indonesia. Proceeding International Conference of Business, Accounting and Economy, 167-172.

McGowan, C. B., \& Ibrihim, I. (2009). An Analysis Of The Day-Of-The-Week Effect In The Russian Stock Market. International Business \& Economics Research 
Journal (IBER), 8(9), 25-30. https:/ / doi.org/10.19030/iber.v8i9.3165

Mehdian, S., \& Perry, M. J. (2001). The reversal of the monday effect: New evidence from US equity markets. Journal of Business Finance and Accounting, 28(7-8), 1043-1065. https://doi.org/10.1111/1468-5957.00404

Muhammad, N. M. N., \& Rahman, N. M. N. A. (2010). Efficient Market Hypothesis and Market Anomaly: Evidence from Day-of-the Week Effect of Malaysian Exchange. International Journal of Economics and Finance, 2(2), 36-42.

Nasir, M. A., Rossi, M., \& Khan, K. (2017). The calendar anomalies on performance and volatility of stock market: the effects of Ramadan on Karachi Stock Exchange. Global Business and Economics Review, 19(1), 54-69. https://doi.org/10.1504/gber.2017.10000917

Perez, G. G. A. (2018). Monday effect in the Chinese Stock Market. International Journal of Financial Research, 9(1), 1-7. https://doi.org/10.5430/ijfr.v9n1p1

Putra, I. K. T. D., \& Ardiana, P. A. (2016). Analisis The Monday Effect Di Bursa Efek Indonesia. E-Jurnal Akuntansi Universitas Udayana, 17(1), 591-614.

Rahmawati, S., \& Hidayati, L. N. (2016). Analisis Monday Effect dan Weekend Effect Pada Return Saham Perusahaan LQ 45 di Bursa Efek Indonesia. Manajemen Universitas Negeri Yogyakarta, 551-561.

Roseliani, B., \& Khairunnisa. (2015). Efek Anomali Pasar Terhadap Return Saham (Perusahaan LQ-45 Yang Terdaftar Di Bursa Efek Indonesia Periode 2013). EProceeding of Management, 2(2), 1649-1658. Retrieved from www.idx.co.id

Rossi, M. (2015). The efficient market hypothesis and calendar anomalies: A literature review. International Journal of Managerial and Financial Accounting, 7(3-4), 285-296. https:// doi.org/10.1504/IJMFA.2015.074905

Rystrom, D. S., \& Benson, E. D. (1989). Investor Psychology and the Day-of-theWeek Effect. Financial Analysts Journal, 45(5), 75-78. https://doi.org/10.2469/ faj.v45.n5.75

Saraswati, Y. R., Setiorini, C., \& Cornelia, D. A. (2015). Pengaruh The Day Of The Week Effect, Week Four Effect, dan Rogalsky Effect terhadap Return Saham LQ-45 di Bursa Efek Indonesia. Jurnal Riset Akuntansi Dan Perpajakan, 2(1), 4354 .

Shahid, M. N., \& Mehmood, Z. (2015). Calendar Anomalies in Stock Market: A Case of KSE 100 Index. International Journal of African Adn Asian Studies, 7, 1624.

Sias, R. W., \& Starks, L. T. (1995). The Day-of-the-Week Anomaly: The Role of Institutional Investors. Financial Analysts Journal, 51(3), 58-67. https://doi.org/10.2469/ faj.v51.n3.1906

Sulaiman, \& Handi, A. (2008). Pengaruh Kinerja Keuangan terhadap Return Saham pada Perusahaan Manufaktur di BEJ. Vol: 2 No. 2 Juli 2008. Jurnal Penelitian Dan Pengembangan Akuntansi, 2(2).

Trisnadi, M. M., \& Sedana, I. B. P. (2016). Pengujian Anomali Pasar : Day Of The Week Effect Pada Saham LQ-45 di Bursa Efek Indonesia. E-Jurnal Manajemen Unud, 5(6), 3794-3820.

Wang, K., Li, Y., \& John, E. (1997). American Finance Association A New Look at the Monday Effect. 52(5), 2171-2186.

Wulandari, F., \& Diana, N. (2018). Analisis Monday Effect Dan Friday Effect Pada Indeks Likuiditas 45 di Bursa Efek Indonesia. E-Jurnal Ilmiah Riset Akuntansi. 